\title{
PEMETAAN SOSIAL SEBARAN KRIMINALITAS DI KOTA SAMARINDA BERBASIS SINGLE EXPONENTIAL SMOOTHING DAN SISTEM INFORMASI GEOGRAFIS
}

\author{
Indah Fitri Astuti $^{1)}$, Ekky Fardinan ${ }^{2}$, Addy Suyatno ${ }^{3)}$ \\ ${ }^{1,2,3}$ Ilmu Komputer, Fakultas Ilmu Komputer dan Teknologi Informasi, Universitas Mulawarman \\ ${ }^{1,2,3} \mathrm{Jl}$. Barong Tongkok Kampus Gunung Kelua, Samarinda, 75121 \\ E-mail : indahfitriastuti@gmail.com ${ }^{1)}$, ekky_fardinan@yahoo.com ${ }^{2)}$, addyshadisuwito@gmail.com ${ }^{3)}$
}

\begin{abstract}
ABSTRAK
Kriminalitas adalah bentuk perbuatan sosial yang melanggar norma hukum yang berkaitan dengan perbuatan merampas hak milik orang lain, mengganggu ketertiban masyarakat, dan pembunuhan satu maupun sekelompok orang. Tindak kriminalitas terjadi karena adanya kepincangan sosial, kebencian, tekanan mental, ataupun perubahan lingkungan yang terjadi di masyarakat. Samarinda merupakan salah satu kota terpadat di Provinsi Kalimantan Timur yang memiliki rentetan kasus kriminalitas yang sangat tinggi menurut Kepolisian Negara Republik Indonesia Resor Kota Samarinda dan tercatat 2.783 laporan kriminal terjadi pada tahun 2016. Sistem Informasi Geografis (SIG) merupakan sistem informasi berbasis komputer yang digunakan untuk mengolah, menyimpan, mengumpulkan, menimbun, dan mengambil kembali data yang diinginkan dan penayangan data keruangan yang berasal dari kenyataan dunia.
\end{abstract}

Tujuan penelitian ini adalah memodifikasi peta Samarinda dengan informasi sebaran daerah perseberan kriminal agar dapat menjadi peringatan bagi para penduduk maupun pendatang tentang daerah rawan, daerah berbahaya, maupun daerah yang jarang terjadi kriminalitas.

Studi ini menggunakan metode Single Exponential Smoothing yang merupakan salah satu metode peramalan kuantitatif dengan menambahkan parameter $\alpha$ dalam modelnya untuk mengurangi faktor acak dalam menghitung data akan datang berdasarkan perhitungan data sebelumnya. Hasil yang dicapai dari penelitian ini menerapkan metode peramalan dalam SIG yang dapat memberikan informasi mengenai kriminalitas yang ada di 10 Kecamatan Kota Samarinda sebagai acuan untuk meningkatkan kewaspadaan masyarakat dalam menghadapi bahaya kriminalitas di Kota Samarinda.

Kata Kunci: Kriminalitas, Pemetaan, Sebaran, Sistem Informasi Geografis, Single Exponential Smoothing

\section{PENDAHULUAN}

Kriminalitas adalah sebuah bentuk perbuatan sosial yang melanggar norma hukum yang berkaitan dengan perbuatan merampas hak milik orang lain, mengganggu ketertiban masyarakat, dan pembunuhan satu maupun sekelompok orang. Tindak kriminalitas terjadi karena adanya kepincangan sosial, kebencian, tekanan mental, ataupun perubahan lingkungan yang terjadi di masyarakat.

Samarinda merupakan Ibukota Provinsi Kalimantan Timur dengan jumlah penduduk laki laki sebanyak 435.959 jiwa dan perempuan 407.497 jiwa menurut data Badan Pusat Statistik Provinsi Kalimantan Timur. Kota Samarinda memiliki 10 kecamatan yang terdiri dari 59 kelurahan yang tidak sedikit memiliki rentetan kasus kriminalitas setiap harinya.

Badan Reserse Kriminal (Bareskrim) Kota Samarinda mencatat 3.416 laporan yang diterima pada jangka waktu Januari 2016 sampai dengan Maret 2017, sebagian besar adalah tindak kriminal curanmor (pencurian kendaraan bermotor), pencurian biasa, penggelapan, dan lain sebagainya. Kurangnya informasi untuk masyarakat akan lingkungan sekitar adalah salah satu penyebabnya, dengan tidak waspadanya masyarakat dengan mudahnya para pelaku kriminal melakukan aksinya.

Berdasarkan latar belakang tersebut maka dibutuhkan sebuah sistem informasi untuk memberikan informasi untuk masyarakat Kota Samarinda dimana masyarakat dapat mengetahui tentang wilayah wilayah yang rawan akan kriminalitas beserta jenis-jenis kriminal yang sering terjadi dalam berapa bulan terakhir.

Tujuan dibuatnya sistem informasi ini untuk mencegah terjadinya tindak kriminal dan dapat meningkatkan kewaspadaan masyarakat Kota Samarinda terhadap kondisi kriminalitas di kota. Penulis dalam perancangannya akan membangun sebuah sistem informasi tentang pemetaan kriminalitas yang berbasis web sehingga dapat memberikan informasi dan pemetaan wilayah yang menggambarkan persebaran kriminalitas di kota Samarinda. 


\section{RUANG LINGKUP PENELITIAN}

Ruang lingkup alam penelitian ini dibatasi pada:

1. Sebaran peta kriminalitas mencakup wilayah kota Samarinda.

2. Masukan sistem adalah data Kepolisian Negara Republik Indonesia Resor Kota Samarinda.

3. Visualisasi peta menggunakan Google Map.

4. Keluaran sistem adalah perhitungan untuk menentukan daerah rawan, daerah berbahaya, dan daerah jarang terjadinya kasus dalam batasan kecamatan-kecamatan yang ada di kota Samarinda.

\section{BAHAN DAN METODE}

Metode-metode dan bahan yang digunakan dalam penelitian ini adalah:

\subsection{Sistem Informasi Geografis}

Sistem Informasi Geografis atau SIG atau yang lebih dikenal dengan GIS mulai dikenal pada awal 1980-an. Sejalan dengan berkembangnya perangkat komputer, baik perangkat lunak maupun perangkat keras, SIG mulai berkembang sangat pesat pada era 1990an dan saat ini semakin berkembang. Sistem Informasi Geografis (SIG) atau Geographic Information System (GIS) merupakan sistem informasi berbasis komputer yang digunakan untuk mengolah dan menyimpan data atau informasi geografis (Robi'in, 2008).

SIG merupakan alat yang bermanfaat untuk pengumpulan, penimbunan, pengambilan kembali data yang diinginkan dan penayangan data keruangan yang berasal dari kenyataan dunia. Secara umum pengertian SIG adalah Suatu komponen yang terdiri dari perangkat keras, perangkat lunak, sumberdaya manusia dan data yang bekerja bersama secara efektif untuk memasukan, menyimpan, memperbaiki, memperbaharui, mengelola, memanipulasi, mengintegrasikan, menganalisa dan menampilkan data dalam suatu informasi berbasis geografis. Komponen SIG disajikan pada gambar 1.

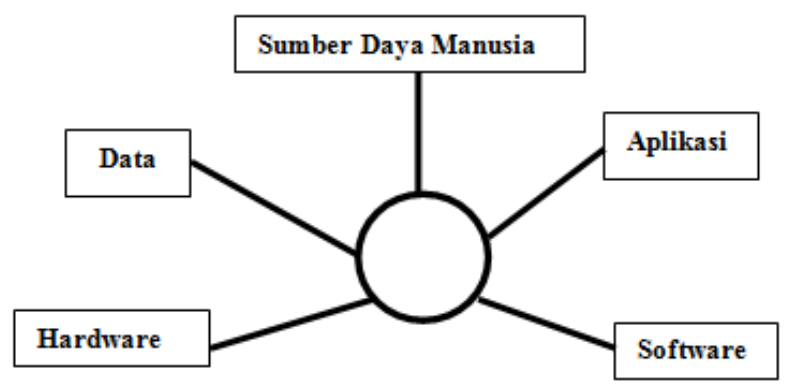

Gambar 1. Komponen SIG

SIG mempunyai kemampuan untuk menghubungkan berbagai data pada suatu titik tertentu di bumi, menggabungkannya, menganalisa dan akhirnya memetakan hasilnya. Data yang akan diolah pada SIG merupakan data spasial yaitu sebuah data yang berorientasi geografis dan merupakan lokasi yang memiliki sistem koordinat tertentu, sebagai dasar referensinya. Sehingga aplikasi SIG dapat menjawab beberapa pertanyaan seperti; lokasi, kondisi, trend, pola dan pemodelan. Kemampuan inilah yang membedakan SIG dari sistem informasi lainnya.

\subsection{Single Exponential Smoothing}

Metode Single Exponential Smoothing sebenarnya merupakan perkembangan dati metode Moving Average sederhana (Prayuda, 2013), yang dijelaskan pada rumus:

$$
\begin{aligned}
& S_{t+1}=\frac{x_{t}+X_{t-1}+\ldots .+X_{t-n+1}}{n} \\
& S_{t+1}=\frac{X_{t}}{n}+\frac{X_{t-1}}{n}+\ldots . .+\frac{x_{t-n+1}}{n}
\end{aligned}
$$

dan

$$
\begin{aligned}
& S_{t}=\frac{x_{t-1}+x_{t-2}+\ldots .+x_{t-n}}{n} \\
& S_{t}=\frac{x_{t-1}}{n}+\frac{x_{t-2}}{n}+\ldots . .+\frac{x_{t-n}}{n}
\end{aligned}
$$

Perbedaan antara $S_{t+1}$ dan $S_{t}$ adalah:

a. Pada $S_{t+1}$ terdapat Error! Reference source not found. sedangkan pada $S_{t}$ tidak terdapat.

b. Pada $S_{t}$ terdapat Error! Reference source not found. sedangkan pada $S_{t+1}$ tidak terdapat.

Jika nilai $S_{t}$ sudah diketahui maka nilai $S_{t+1}$ dapat dicari berdasarkan nilai $S_{t}$ tersebut.

$$
S_{t+1}=\frac{x_{t}}{n}+S_{t}-\frac{x_{t-n}}{n}
$$

Jika Error! Reference source not found. diganti dengan nilai peramalan pada tahun $\mathrm{t}$ (yaitu $\mathrm{S}_{\mathrm{t}}$ ), maka persamaan tersebut berubah menjadi:

$$
S_{t+1}=\frac{x_{t}}{n}+S_{t}-\frac{S_{t}}{n}
$$

Dapat dirubah lagi menjadi:

$$
\mathrm{S}_{\mathrm{t}+1}=\frac{1}{\mathrm{n}} \mathrm{X}_{\mathrm{t}}+\left(1-\frac{1}{\mathrm{n}}\right) \mathrm{S}_{\mathrm{t}}
$$

Metode Exponential Smoothing dengan nilai Error! Reference source not found. diganti dengan $\alpha$, sehingga rumus peramalannya menjadi:

$$
\mathrm{S}_{\mathrm{t}+1}=\alpha \mathrm{X}_{\mathrm{t}}+(1-\alpha) \mathrm{S}_{\mathrm{t}}
$$

$\mathrm{S}_{\mathrm{t}+1}=$ nilai peramalan satu periode kedepan

$\mathrm{X}_{\mathrm{t}} \quad=$ data aktual pada periode ke $\mathrm{t}$

$\mathrm{S}_{\mathrm{t}} \quad=$ nilai peramalan pada periode ke $\mathrm{t}$

$\alpha=$ nilai konstanta parameter

Ketepatan dalam banyak situasi peramalan dipandang sebagai kriteria penolakan untuk memilih suatu metode peramalan. Bagi pemakai ramalan, ketepatan ramalan yang akan datang sangat penting. Ketepatan metode ramlan dilihat dari kesalahan peramalan. Kesalahan peramalan merupakan ukuran ketepatan dan menjadi dasar untuk membandingkan kinerja. Dalam penelitian ini digunakan Mean Absolute Percentage Error (MAPE) untuk pemilihan metode terbaik serta mengetahui ketepatan peramalan (Utami, 2015). Adapun rumus MAPE adalah:

$$
\mathrm{MAPE}=\frac{1}{\mathrm{n}} \sum_{\mathrm{t}=1}^{\mathrm{n}}\left|\mathrm{PE}_{\mathrm{t}}\right|
$$


$\mathrm{n}$ adalah banyaknya periode dan $\mathrm{PE}_{\mathrm{t}}$ adalah kesalahan persentase.

$$
P E_{t}=\left(\frac{x_{t}-F_{t}}{x_{t}}\right) 100 \%
$$

$\mathrm{X}_{\mathrm{t}} \quad=$ observasi pada periode ke $\mathrm{t}$.

$\mathrm{F}_{\mathrm{t}} \quad=$ ramalan pada periode ke $\mathrm{t}$.

Semakin kecil nilai MAPE berarti nilai taksiran semakin mendekati nilai sebenarnya.

\subsection{Bentuk Tindakan Kriminal}

Tindakan kriminal umumnya dilihat bertentangan dengan norma hukum, norma sosial dan norma agama yang berlaku di masyarakat (Maslichah, 2012).

Bentuk-bentuk tindak kriminal adalah pencurian, tindak asusila, pencopetan, penjambretan, penodongan dengan senjata tajam/api, penganiayaan, pembunuhan, penipuan, dan korupsi.

\section{RANCANGAN SISTEM}

Pelaksanaan penelitian dilakukan di Kantor Polisi Resor Kota Samarinda divisi khusus Bareskrim.

Tahap awal perancangan penelitian ini menggunakan UML. UML adalah sebuah bahasa yang telah menjadi standar dalam industri untuk visualisasi, merancang dan mendokumentasikan sistem piranti lunak. UML menawarkan sebuah standar untuk merancang model sebuah sistem (Nugroho, 2009). Tahap ini merupakan tahap perancangan logis aplikasi, termasuk didalamnya proses aturan yang digunakan, user interface, susunan pilihan menu, database dan masukan yang dibutuhkan.

Perancangan sistem yang dilakukan diawali dengan menyusun studi literatur tentang kriminalitas, peramalan dan sistem informasi geografis. Tahap perancangan dapat menemukan masalah, tujuan, dan manfaat dalam penelitian yang dilakukan.

Aplikasi yang akan dirancang membutuhkan studi tentang pemrograman berbasis web. Tools yang akan digunakan adalah PHP, CSS, MySQL, dan JavaScript.

Perancangan sistem adalah rencana sistematis dalam proses pengembangan sistem setelah data cukup untuk menunjang kegiatan pengembangan sistem. Dalam perancangan sistem ini menggunakan diagram UML yaitu use case.

Use case diagram untuk Super Admin memiliki aktor yaitu super admin, dimana admin dapat mengolah data admin, data kriminal, dan mengolah hasil data kriminal. Seorang super admin dapat menambah atau mengubah data admin dan memasukkan data aktual data kriminal namun sebelum melakukan perhitungan terlebih dahulu pengguna diharuskan memasukkan nilai data aktual yang telah dihitung lalu akan diproses untuk pemetaan yang dilakukan oleh sistem, seperti disajikan pada gambar 2 .

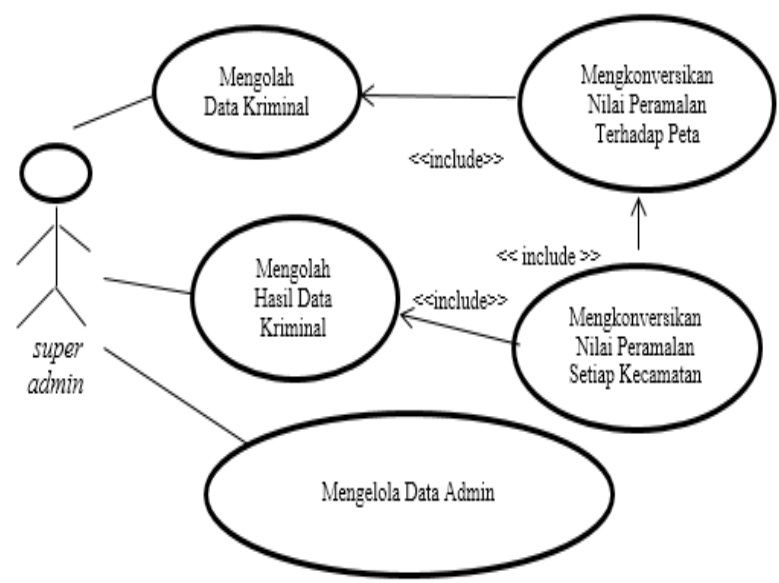

Gambar 2. Use Case Diagram Super Admin Sistem

Use case diagram untuk Admin memiliki aktor yaitu admin, dimana admin dapat mengolah data kriminal, dan mengolah hasil data kriminal. Seorang admin dapat melakukan perhitungan peramalan namun sebelum melakukan perhitungan terlebih dahulu pengguna diharuskan memasukkan nilai data peramalan yang telah dikonversikan pada sistem lalu akan diproses untuk pemetaan yang dilakukan oleh sistem.

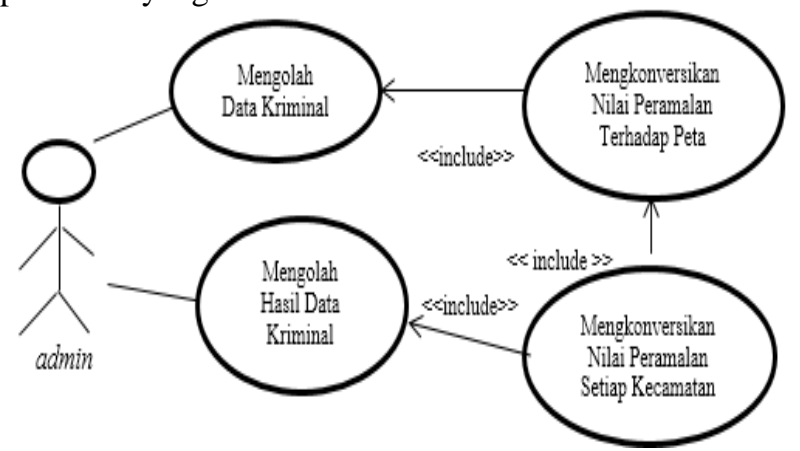

Gambar 3. Use Case Diagram Admin Sistem

Kerangka kerja penelitian dapat dilihat pada gambar 4. Tahap awal dilakukan studi literatur terhadap penelitian yang akan dilakukan untuk memahami batasan batasan dan cakupan penelitian agar tujuan penelitian tercapai. Selain itu juga mencari penelitian penelitian sejenis yang sesuai dengan topik penelitian untuk menambah wawasan dan pemahaman terhadap topik yang dibahas pada penelitian. Observasi data terkait dilakukan di Badan Reserse Kriminal Kepolisian Resor Kota Samarinda, untuk mendapat data yang diperlukan dalam melakukan penelitian. Selain melakukan observasi juga dilakukan survei data kepada pihak kepolisian untuk melengkapi data yang dibutuhkan.

Tabulasi data merupakan bagian dalam analisis masalah untuk merinci data agar dapat diolah dalam sistem yang akan dibangun. Perancangan perhitungan juga dibutuhkan dalam analisa sistem seperti perhitungan nilai nilai peramalan, penentuan konstanta peramalan, dan analisis metode single exponential smoothing.

Tahap terakhir ialah implementasi sistem dimana perhitungan dan data dikumpulkan lalu diubah menjadi sebuah sistem informasi geografis. Sehingga, dapat 
ditemukan temuan dan bahasan hasil penelitian yang dilakukan.

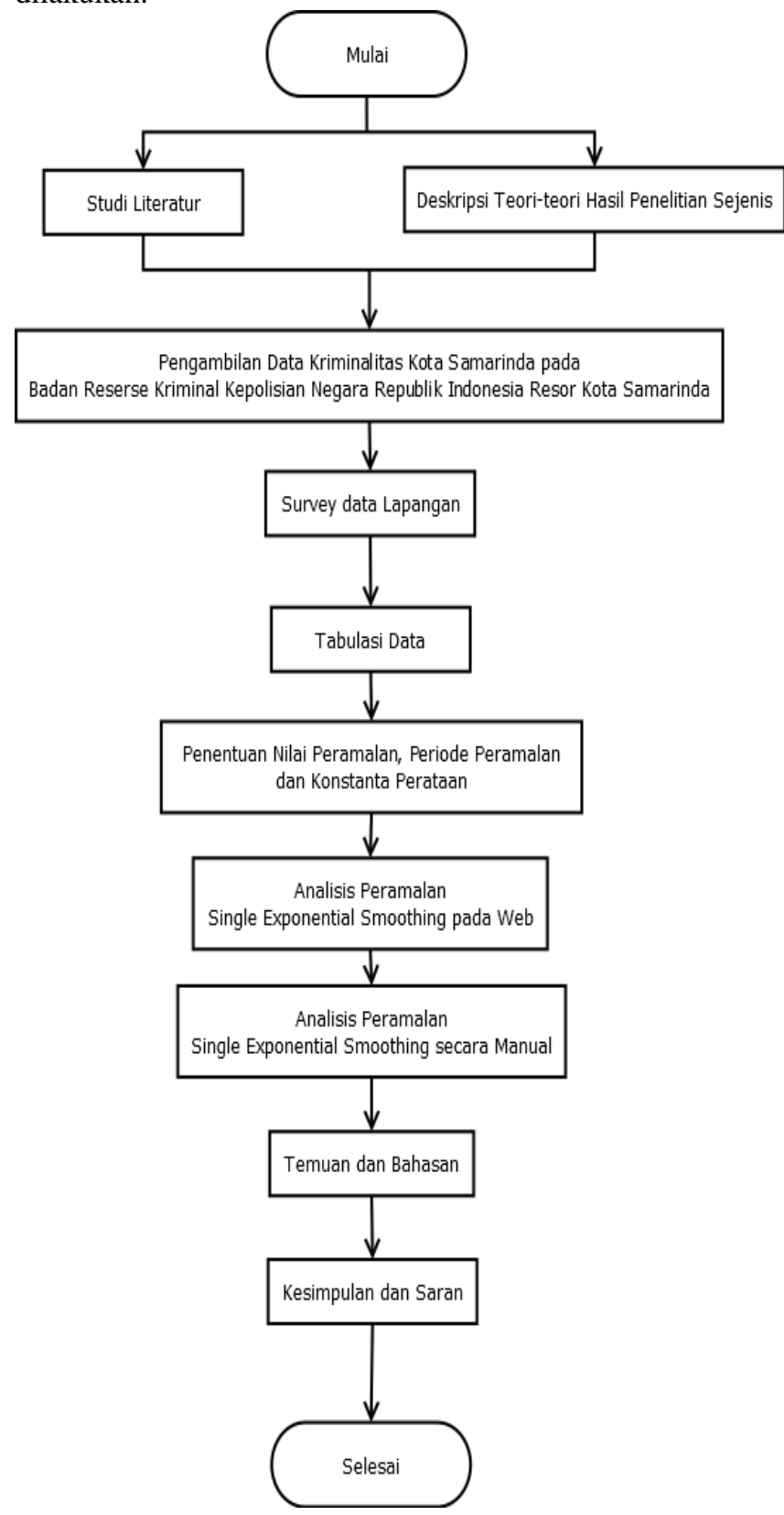

Gambar 4. Kerangka Kerja Penelitian

\section{IMPLEMENTASI}

Sistem informasi geografis pemetaan kriminalitas ini adalah peramalan Single Exponential Smoothing yaitu pengolahan data kriminal dari pihak kepolisian per bulan yang telah dimasukkan ke dalam sebuah rumus peramalan dengan menghitung secara deret laporan kriminal pada setiap wilayah Samarinda sehingga dapat diramalkan jumlah laporan kriminal di bulan berikutnya.

Peramalan pemetaan sosial kriminalitas ini menggunakan metode Single Exponential Smoothing, memiliki berberapa konstanta peramalan $(\alpha)$ berdasarkan setiap kecamatan di Kota Samarinda. Konstanta peramalan ini didapatkan dengan cara melakukan perhitungan terhadap setiap sampel data kriminalitas di setiap kecamatan perbulannya. Penentuan konstanta peramalan di setiap wilayahnya, hasil peramalan lalu diterapkan kepada peta GoogleMapsAPI untuk memperlihatkan wilayah wilayah yang telah diramalkan bedasarkan perhitungan yang telah dilakukan.

Sistem ini memiliki satu super admin yaitu kepala bidang Divisi Bareskrim Resor Kota Samarinda dan satu admin yaitu pegawai dari Divisi Bareskrim Resor Kota Samarinda. Ada berberapa alur aktifitas yang dapat dilakukan oleh kepala bidang seperti, mengelola user, mengelola data laporan kriminalitas per bulan, dan mengelola data kriminalitas per wilayahnya dan untuk pegawai hanya dibatasi dalam mengelola data laporan kriminal perbulan. Setelah semua proses selesai super admin maupun admin dapat keluar dari sistem.

Sistem informasi geografis pemetaan sosial kriminalitas ini menggunakan metode single exponential smoothing yang dapat menghasilkan informasi pemetaan yang sesuai dengan data kriminal dari Kepolisian Republik Indonesia Resor Kota Samarinda.

\subsection{Analisis Algoritma}

Analisis algoritma dilakukan selama proses implementasi untuk mengetahui apakah sistem mampu melakukan fungsinya sesuai yang diharapkan. Sistem pengujian dilakukan dengan menganalisis data kriminal yang telah didapat dari Kepolisian Resor Kota Samarinda divisi Bareskrim, berikutnya menerapkan perhitungan peramalan dengan metode Single Exponential Smoothing dengan menentukan konstanta peramalan terlebih dahulu. Tahap berikutnya adalah proses output dimana diterapkan dalam peta GoogleMap dimana menggunakan GoogleFusionTables.

Data Gangguan Kamtibmas(Keamanan dan Ketertiban Masyarakat) berdasarkan Kantor Polres Kota Samarinda dan seluruh Kantor Polsek Kota Samarinda bulan Januari - Mei Tahun 2017 disajikan pada tabel 1:

Tabel 1. Kamtibmas Kota Samarinda Januari 2017-

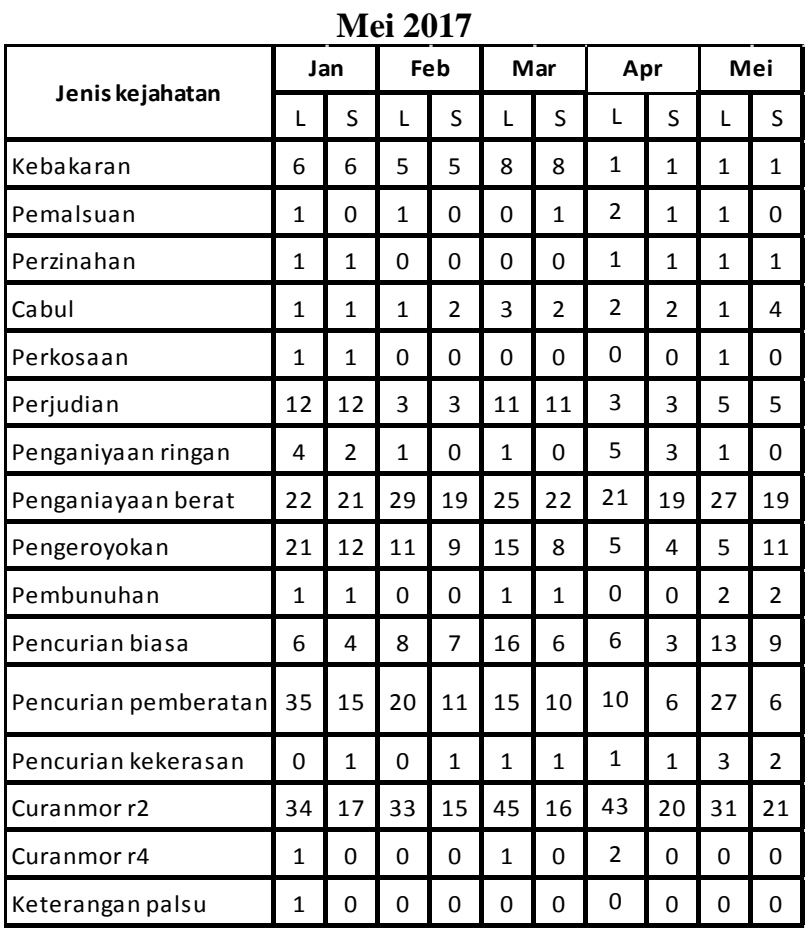




\begin{tabular}{|l|c|c|c|c|c|c|c|c|c|c|}
\hline Penipuan & 14 & 10 & 9 & 5 & 11 & 7 & 14 & 9 & 5 & 5 \\
\hline Penggelapan & 29 & 15 & 33 & 22 & 37 & 13 & 25 & 12 & 19 & 10 \\
\hline Peras / ancam & 2 & 0 & 1 & 0 & 1 & 4 & 2 & 1 & 5 & 2 \\
\hline Pengancaman & 2 & 1 & 3 & 2 & 1 & 1 & 2 & 2 & 1 & 1 \\
\hline KDRT & 11 & 11 & 6 & 5 & 4 & 6 & 4 & 1 & 6 & 6 \\
\hline Perlindungan anak & 13 & 13 & 2 & 3 & 7 & 5 & 6 & 6 & 8 & 7 \\
\hline Sajam & 2 & 2 & 3 & 3 & 3 & 3 & 6 & 6 & 3 & 3 \\
\hline Penyerobotan tanah & 0 & 1 & 0 & 0 & 0 & 0 & 0 & 0 & 1 & 1 \\
\hline Membawa lari anak & 0 & 0 & 0 & 0 & 0 & 0 & 0 & 0 & 0 & 0 \\
\hline Pengrusakan & 3 & 3 & 2 & 0 & 7 & 3 & 0 & 0 & 0 & 0 \\
\hline Miras & 1 & 1 & 0 & 0 & 0 & 0 & 0 & 0 & 0 & 0 \\
\hline Penghinaan / ITE & 1 & 1 & 2 & 0 & 1 & 0 & 0 & 0 & 0 & 1 \\
\hline Penadahan & 0 & 1 & 0 & 3 & 0 & 4 & 0 & 2 & 0 & 0 \\
\hline $\begin{array}{l}\text { Masuk rumah tanpa } \\
\text { izin }\end{array}$ & 1 & 0 & 0 & 0 & 0 & 0 & 1 & 0 & 1 & 0 \\
\hline $\begin{array}{l}\text { Lain lain / temu mayat, } \\
\text { ketertiban umum dlI }\end{array}$ & 4 & 3 & 8 & 8 & 8 & 8 & 7 & 7 & 8 & 8 \\
\hline
\end{tabular}

Keterangan :

$\mathrm{L}=$ Kasus yang dilaporkan,

$\mathrm{S}=$ Kasus yang telah diselesaikan.

Berdasarkan tabel 1, kota Samarinda memiliki 8 kantor Polres dan Polsek yang tersebar di seluruh Kota Samarinda. Hal ini tidak sesuai dengan jumlah Kecamatan yang ada pada wilayah administratif Kota Samarinda dengan 10 Kecamatan.

Analisis data dilakukan dengan melakukan wawancara terhadap pihak Kepolisian Resor Kota Samarinda Divisi Bareskrim Kepala Urbin Ops sehingga data Kamtibmas dapat disesuaikan dengan 10 Kecamatan yang ada di Kota Samarinda.

\subsection{Single Exponential Smoothing dan Pengujian}

Perhitungan peramalan Single Exponential Smoothing yang akan dihitung harus memiliki data aktual dari kecamatan yang berdasarkan data kamtibmas Kepolisian Resor Kota Samarinda. Dengan penjabaran data maka perhitungan dimulai dari perhitungan bulan ke-1 hingga bulan terakhir berdasarkan data aktual.

Perhitungan akan dilakukan menggunakan konstanta peramalan dengan range 0-1 maka perhitungan konstanta peramalan dimulai dari $(\alpha=0,1),(\alpha=0,2),(\alpha=0,3),(\alpha$ $=0,4),(\alpha=0,5),(\alpha=0,6),(\alpha=0,7),(\alpha=0,8)$, dan $(\alpha=$ $0,9)$. Perhitungan yang akan dilakukan dengan menggunakan data Kecamatan Palaran sedangkan perhitungan 9 kecamatan lainnya akan di lampirkan.

Data Kecamatan Palaran yang akan dihitung peramalannya disajikan pada tabel 3 .
Tabel 3. Data Aktual Kecamatan Palaran

\begin{tabular}{|c|c|}
\hline Bulan & Data \\
\hline Januari & 6 \\
\hline Februari & 4 \\
\hline Maret & 3 \\
\hline April & 0 \\
\hline Mei & 8 \\
\hline
\end{tabular}

Dilakukan perhitungan menggunakan rumus Single Exponential Smoothing terhadap data setiap bulannya dengan menggunakan konstanta peramalan $(\alpha=0,1),(\alpha$ $=0,2),(\alpha=0,3),(\alpha=0,4),(\alpha=0,5),(\alpha=0,6),(\alpha=0,7)$, $(\alpha=0,8)$, dan $(\alpha=0,9)$. Pada saat $\mathrm{t}=1$, nilai $\mathrm{S}_{1}$ (peramalan pada periode pertama) belum tersedia, maka untuk mengatasi masalah ini dapat dilakukan dengan menetapkan nilai $S_{1}$ sama dengan nilai data periode pertama $\left(X_{1}\right)$ yaitu $S_{1}=6$.

Perhitungan dilanjutkan dengan menemukan persentase kesalahan dengan menghitung hasil peramalan dikurang dengan data aktual lalu dihitung persentase kesalahannya, dengan menghitung rata rata keseluruhan persentase kesalahan, maka nilai MAPE dapat ditemukan.

a) Perhitungan Konstanta $\alpha=0,1$

$\mathrm{S}_{2}=\alpha \mathrm{X}_{1}+(1-\alpha) \mathrm{S}_{1}$

$\mathrm{S}_{2}=(0,1 *$ Data Kriminal Bulan Januari $)+(1-0,1) * \mathrm{~S}_{1}$

$\mathrm{S}_{2}=(0,1 * 6)+(1-0,1) 6$

$\mathrm{S}_{2}=6$

$\mathrm{S}_{3}=\alpha \mathrm{X}_{2}+(1-\alpha) \mathrm{S}_{2}$

$\mathrm{S}_{3}=(0,1 *$ Data Kriminal Bulan Februari $)+(1-0,1) * S_{2}$

$\mathrm{S}_{3}=(0,1 * 4)+(1-0,1) 6$

$\mathrm{S}_{3}=5,8$

$\mathrm{S}_{4}=\alpha \mathrm{X}_{3}+(1-\alpha) \mathrm{S}_{3}$

$\mathrm{S}_{4}=(0,1 *$ Data Kriminal Bulan Maret $)+(1-0,1) * \mathrm{~S}_{3}$

$\mathrm{S}_{4}=(0,1 * 3)+(1-0,1) 5,8$

$\mathrm{S}_{4}=5,52$

$\mathrm{S}_{5}=\alpha \mathrm{X}_{4}+(1-\alpha) \mathrm{S}_{4}$

$\mathrm{S}_{5}=(0,1 *$ Data Kriminal Bulan April $)+(1-0,1) * \mathrm{~S}_{4}$

$\mathrm{S}_{5}=(0,1 * 0)+(1-0,1) 5,5$

$\mathrm{S}_{5}=4,97$

$\mathrm{S}_{6}=\alpha \mathrm{X}_{5}+(1-\alpha) \mathrm{S}_{5}$

$\mathrm{S}_{6}=(0,1 *$ Data Kriminal Bulan Mei $)+(1-0,1) * \mathrm{~S}_{5}$

$\mathrm{S}_{6}=(0,1 * 8)+(1-0,1) 4,97$

$\mathrm{S}_{6}=5,27$

b) Perhitungan Konstanta $\alpha=0,2$

$\mathrm{S}_{2}=\alpha \mathrm{X}_{1}+(1-\alpha) \mathrm{S}_{1}$

$\mathrm{S}_{2}=(0,2 *$ Data Kriminal Bulan Januari $)+(1-0,2) * \mathrm{~S}_{1}$

$\mathrm{S}_{2}=(0,2 * 6)+(1-0,2) 6$

$\mathrm{S}_{2}=6$

$S_{3}=\alpha X_{2}+(1-\alpha) S_{2}$

$S_{3}=(0,2 *$ Data Kriminal Bulan Februari $)+(1-0,2) * S_{2}$ 
$\mathrm{S}_{3}=(0,2 * 4)+(1-0,2) 6$

$\mathrm{S}_{3}=5,6$

$\mathrm{S}_{4}=\alpha \mathrm{X}_{3}+(1-\alpha) \mathrm{S}_{3}$

$\mathrm{S}_{4}=(0,2 *$ Data Kriminal Bulan Maret $)+(1-0,2) * \mathrm{~S}_{3}$

$\mathrm{S}_{4}=(0,2 * 3)+(1-0,2) 5,6$

$\mathrm{S}_{4}=5,08$

$\mathrm{S}_{5}=\alpha \mathrm{X}_{4}+(1-\alpha) \mathrm{S}_{4}$

$\mathrm{S}_{5}=(0,2 *$ Data Kriminal Bulan April $)+(1-0,2) * \mathrm{~S}_{4}$

$\mathrm{S}_{5}=(0,2 * 0)+(1-0,2) 5,08$

$\mathrm{S}_{5}=4,06$

$\mathrm{S}_{6}=\alpha \mathrm{X}_{5}+(1-\alpha) \mathrm{S}_{5}$

$\mathrm{S}_{6}=(0,2 *$ Data Kriminal Bulan Mei $)+(1-0,2) * \mathrm{~S}_{5}$

$\mathrm{S}_{6}=(0,2 * 8)+(1-0,2) 4,06$

$\mathrm{S}_{6}=4,85$

Demikian dihitung sampai dengan konstanta 0,8 dan 0,9

Perhitungan Konstanta $\alpha=0,8$

$\mathrm{S}_{2}=\alpha \mathrm{X}_{1}+(1-\alpha) \mathrm{S}_{1}$

$\mathrm{S}_{2}=(0,8 *$ Data Kriminal Bulan Januari $)+(1-0,8) * \mathrm{~S}_{1}$

$\mathrm{S}_{2}=(0,8 * 6)+(1-0,8) 6$

$\mathrm{S}_{2}=6$

$S_{3}=\alpha X_{2}+(1-\alpha) S_{2}$

$\mathrm{S}_{3}=(0,8 *$ Data Kriminal Bulan Februari $)+(1-0,8) * \mathrm{~S}_{2}$

$\mathrm{S}_{3}=(0,8 * 4)+(1-0,8) 6$

$\mathrm{S}_{3}=4,4$

$\mathrm{S}_{4}=\alpha \mathrm{X}_{3}+(1-\alpha) \mathrm{S}_{3}$

$\mathrm{S}_{4}=(0,8 *$ Data Kriminal Bulan Maret $)+(1-0,8) * \mathrm{~S}_{3}$

$\mathrm{S}_{4}=(0,8 * 3)+(1-0,8) 4,4$

$\mathrm{S}_{4}=3,28$

$\mathrm{S}_{5}=\alpha \mathrm{X}_{4}+(1-\alpha) \mathrm{S}_{4}$

$\mathrm{S}_{5}=(0,8 *$ Data Kriminal Bulan April $)+(1-0,8) * \mathrm{~S}_{4}$

$\mathrm{S}_{5}=(0,8 * 0)+(1-0,8) 3,28$

$\mathrm{S}_{5}=0,66$

$\mathrm{S}_{6}=\alpha \mathrm{X}_{5}+(1-\alpha) \mathrm{S}_{5}$

$\mathrm{S}_{6}=(0,8 *$ Data Kriminal Bulan Mei $)+(1-0,8) * \mathrm{~S}_{5}$

$\mathrm{S}_{6}=(0,8 * 8)+(1-0,8) 0,66$

$\mathrm{S}_{6}=6,53$

Perhitungan Konstanta $\alpha=0,9$

$\mathrm{S}_{2}=\alpha \mathrm{X}_{1}+(1-\alpha) \mathrm{S}_{1}$

$\mathrm{S}_{2}=(0,9 *$ Data Kriminal Bulan Januari $)+(1-0,9) * \mathrm{~S}_{1}$

$\mathrm{S}_{2}=(0,9 * 6)+(1-0,9) 6$

$\mathrm{S}_{2}=6$

$S_{3}=\alpha X_{2}+(1-\alpha) S_{2}$

$\mathrm{S}_{3}=(0,9 *$ Data Kriminal Bulan Februari $)+(1-0,9) * \mathrm{~S}_{2}$

$\mathrm{S}_{3}=(0,9 * 4)+(1-0,9) 6$

$\mathrm{S}_{3}=4,2$

$\mathrm{S}_{4}=\alpha \mathrm{X}_{3}+(1-\alpha) \mathrm{S}_{3}$

$\mathrm{S}_{4}=(0,9 *$ Data Kriminal Bulan Maret $)+(1-0,9) * \mathrm{~S}_{3}$

$\mathrm{S}_{4}=(0,9 * 3)+(1-0,9) 4,2$

$\mathrm{S}_{4}=3,12$

$\mathrm{S}_{5}=\alpha \mathrm{X}_{4}+(1-\alpha) \mathrm{S}_{4}$

$\mathrm{S}_{5}=(0,9 *$ Data Kriminal Bulan April $)+(1-0,9) * \mathrm{~S}_{4}$
$\mathrm{S}_{5}=(0,9 * 0)+(1-0,9) 3,12$

$\mathrm{S}_{5}=0,31$

$\mathrm{S}_{6}=\alpha \mathrm{X}_{5}+(1-\alpha) \mathrm{S}_{5}$

$\mathrm{S}_{6}=(0,9 *$ Data Kriminal Bulan Mei $)+(1-0,9) * \mathrm{~S}_{5}$

$\mathrm{S}_{6}=(0,9 * 8)+(1-0,9) 0,31$

$\mathrm{S}_{6}=7,23$

Hasil perhitungan dari 1 sampai dengan 9 dapat dilihat di tabel 2.

Tabel 2. Hasil perhitungan MAPE

\begin{tabular}{|c|c|}
\hline $\begin{array}{c}\text { Konstanta } \\
\text { Peramalan }\end{array}$ & MAPE \\
\hline$\alpha=0,1$ & $60,41 \%$ \\
\hline$\alpha=0,2$ & $61,96 \%$ \\
\hline$\alpha=0,3$ & $63,02 \%$ \\
\hline$\alpha=0,4$ & $63,64 \%$ \\
\hline$\alpha=0,5$ & $63,89 \%$ \\
\hline$\alpha=0,6$ & $63,80 \%$ \\
\hline$\alpha=0,7$ & $63,43 \%$ \\
\hline$\alpha=0,8$ & $62,82 \%$ \\
\hline$\alpha=0,9$ & $62,03 \%$ \\
\hline
\end{tabular}

\subsection{Output Hasil Peramalan menggunakan Peta GoogleMap}

Peta yang diolah dibuat parameter untuk mengetahui wilayah mana yang memiliki tingkat kriminalitas rendah, sedang, maupun tinggi. Berdasarkan hasil wawancara terhadap Kepolisian Resor Kota Samarinda divisi Bareskrim ada berberapa parameter yang telah ditentukan.

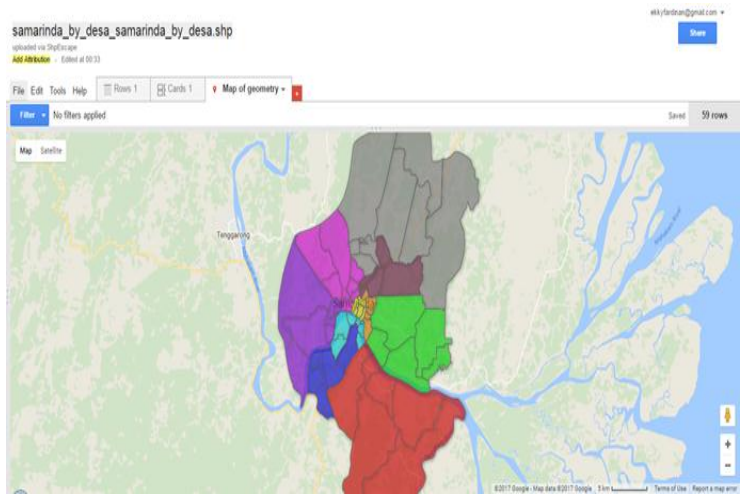

Gambar 5. Peta Kecamatan di kota Samarinda dengan GoogleFusionTable

Sedangkan untuk memudahkan pembacaan peta, maka dibuatlah pembagian warna untuk daerah-daerah di peta berdasarkan keterangan pada tabel 3 .
Tabel 3. Pembagian Keterangan Warna di Peta untuk Tingkat Kriminalitas 


\begin{tabular}{|c|c|c|}
\hline $\begin{array}{c}\text { Jumlah } \\
\text { Kasus }\end{array}$ & $\begin{array}{c}\text { Tingkat } \\
\text { Kriminalitas }\end{array}$ & $\begin{array}{c}\text { Keterangan } \\
\text { Warna }\end{array}$ \\
\hline $0-15$ & Rendah / Jarang & Hijau \\
\hline $16-30$ & Sedang / Rawan & Kuning \\
\hline 30 keatas & $\begin{array}{c}\text { Tinggi / } \\
\text { Berbahaya }\end{array}$ & Merah \\
\hline
\end{tabular}

Pembagian tersebut diimplementasikan terhadap peta berdasarkan hasil perhitungan peramalan yang telah dilakukan terhadap 10 Kecamatan Kota Samarinda. Pembagian keterangan terhadap hasil peramalan dapat dilihat pada tabel 4 .

Tabel 4. Hasil Pemetaan Sebaran Kriminalitas

\begin{tabular}{|c|c|c|c|}
\hline Kecamatan & $\begin{array}{c}\text { Hasil } \\
\text { Peramalan } \\
\text { Bulan } \\
\text { Terakhir } \\
\text { Terhadap } \\
\text { Jumlah Kasus }\end{array}$ & $\begin{array}{c}\text { Tingkat } \\
\text { Kriminalitas }\end{array}$ & $\begin{array}{c}\text { Ket. } \\
\text { Warna }\end{array}$ \\
\hline Palaran & 5,27 & Rendah / Jarang & Hijau \\
\hline $\begin{array}{c}\text { Samarinda } \\
\text { Seberang }\end{array}$ & 32,75 & $\begin{array}{c}\text { Tinggi / } \\
\text { Berbahaya }\end{array}$ & Merah \\
\hline Samarinda Ulu & 34,52 & $\begin{array}{c}\text { Tinggi / } \\
\text { Berbahaya }\end{array}$ & Merah \\
\hline Samarinda Ilir & 9,06 & Rendah / Jarang & Hijau \\
\hline $\begin{array}{c}\text { Samarina } \\
\text { Utara }\end{array}$ & 16,69 & Sedang / Rawan & Kuning \\
\hline $\begin{array}{c}\text { Sungai } \\
\text { Kunjang }\end{array}$ & 35,63 & $\begin{array}{c}\text { Tinggi / } \\
\text { Berbahaya }\end{array}$ & Merah \\
\hline Sambutan & 10,06 & Rendah / Jarang & Hijau \\
\hline Sungai Pinang & 8,26 & Rendah / Jarang & Hijau \\
\hline $\begin{array}{c}\text { Samarinda } \\
\text { Kota }\end{array}$ & 14,16 & Sedang / Rawan & Hijau \\
\hline Loa Janan Ilir & 8,26 & Rendah / Jarang & Hijau \\
\hline
\end{tabular}

Gambar peta akan muncul dengan wilayah wilayah yang telah diberi warna berdasarkan hasil peramalan. Dimana warna hijau adalah wilayah jarang terjadi kriminalitas, warna kuning mewakili wilayah yang tingkat kriminalitasnya sedang, sedangkan merah adalah wilayah yang berbahaya akan kriminalitas.

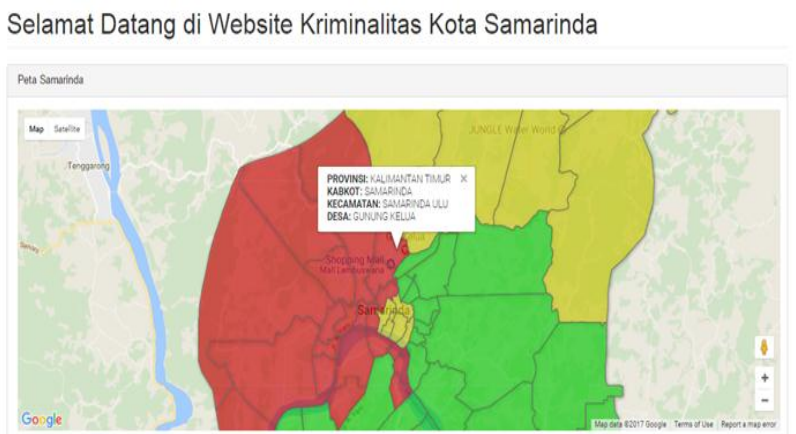

Gambar 6. Halaman Utama Website

\section{KESIMPULAN}

Kesimpulan yang dapat ditarik dari penelitan ini adalah telah dihasilkan sebuah sistem informasi geografis yang mampu memetakan dan memberikan informasi tentang sebaran kriminalitas di kota Samarinda dengan menerapkan peramalan Single Exponential Smoothing dan menemukan bahwa terdapat 3 wilayah berbahaya, 1 wilayah rawan dan 6 wilayah jarang terjadi kejahatan.

\section{SARAN}

Saran yang dapat diberikan untuk penelitian selanjutnya adalah memperkecil wilayah sebaran menjadi per kelurahan dengan menggunakan metode lain seperti Single Moving Average dan Double Exponential Smoothing.

\section{DAFTAR PUSTAKA}

Maslichah, S., 2012, Analisis Pengaruh Faktor Internal dan Eksternal Penyebab Timbulnya Tindakan Kriminal, Surabaya:Institut Teknologi Sepuluh Nopember.

Nugroho, B., 2008, Panduan Lengkap Menguasai Perintah SQL, Jakarta:MediaKita.

Robi'in, B., 2008, Sistem Informasi Geografis Sumber Daya Alam Indonesia Berbasis Web. Yogyakarta: Jurnal Informatika, Vol 2, No. 2, Juli 2008.

Utami, I., 2015, Analisis Pengendalian Persediaan Produk Dengan Metode EOQM Menggunakan Algoritma Genetika untuk Mengefisienkan Biaya Persediaan Hasil Peramalan Berbasis Exponential Smoothing, Samarinda:Universitas Mulawarman. 